\title{
VOLATILE ORGANIC COMPOUNDS IN THE FINISHED WATER OF THE WATER TREATMENT PLANT IN THESSALONIKI, GREECE
}

\author{
N.J. XANTHOPOULOU ${ }^{1, *}$ \\ M.V. PAPAGIANNI ${ }^{1}$ \\ A. PAPAIOANNOU ${ }^{1}$ \\ A. HARALAMBIDOU ${ }^{2}$
}

\author{
${ }^{1}$ Thessaloniki Water Treatment Plant (TWTP) \\ Christoforos D. Constantinidis Constructing Company S.A \\ Rizareiou 18, 152 33, Athens, Greece \\ ${ }^{2}$ Water Supply and Sewerage Company of Thessaloniki \\ Egnatias 127, Thessaloniki, Greece S.A.
}

Selected from papers presented in $9^{\text {th }}$ International Conference on Environmental Science and Technology (9CEST2005)

1-3 September 2005, Rhodes island, Greece *to whom all correspondence should be addressed:

Tel: 30-2310-722727; Fax: 30-2310-722670

e-mail: dithess@the.forthnet.gr;

nxanth@pharm.auth.gr

\begin{abstract}
Chlorination has been the most widely used technology for the disinfection of drinking water around the world. The main purpose for the disinfection of drinking water is to protect it against microbial contamination in the distribution systems and to prevent or at least control re-growth of microorganisms in the pipelines.

A major disadvantage of chlorination is the formation of a wide variety of halogenated compounds from natural organic matter (Rook, 1974; Christman et al., 1983). Some of these by-products, namely trihalomethanes, 1,2-dichloroethane, trichloro- and tetrachloro-ethene have diverse negative effects on human health, including toxicological, mutagenic and carcinogenic effects, as well as induction of congenital malformations and retarded fetal growth (Boorman et al., 1999). Current regulations in Europe demand a target of $100 \mu \mathrm{g} \mathrm{I}^{-1}$ for trihalomethanes (THMs), $3 \mu \mathrm{g} \mathrm{I}^{-1}$ for 1,2-dichloroethane, $10 \mathrm{ug} \mathrm{I}^{-1}$ for the sum of trichloro- and tetrachloroethene, $1 \mu \mathrm{g} \mathrm{I}^{-1}$ for benzene and include all the prementioned compounds in the category of volatile organic compounds (VOCs).

Since September 2003, the city of Thessaloniki and its suburbs are partly supplied with drinking water from the Thessaloniki Water Treatment Plant (TWTP), which takes raw water from the river Aliakmonas. This study presents the regular monitoring results at the TWTP during the period February 2004 - February 2005 for THMs and VOCs included in the European guidelines. At the same time, parameters such as $\mathrm{pH}$, temperature, chlorine demand, total organic carbon (TOC) and contact time $\left(t_{R}\right)$ were monitored.
\end{abstract}

KEYWORDS: THMs, VOCs, drinking water, chlorination, disinfection by-products (DBPs)

\section{INTRODUCTION}

The main reason for drinking water disinfection is protection from microbial contamination in the pipelines along the distribution system, as well as prevention control of regrowth of microorganisms until the water safely reaches the consumers (Rook, 1974 / Christman et al., 1983 / El-Shafy, Grünwald, 2000).

Chlorine has been the most commonly used disinfectant in many water treatment plants. Its popularity arises from its high oxidation potential, low cost and prolonged disinfection effectiveness. The major disadvantage of using free chlorine as a disinfectant is its high and non-selective reactivity, which leads to the formation of disinfection by-products (DBPs) (Çapar, Yetiş, 2002). It rapidly reacts with natural organic matter (NOM), 
principally humic and fulvic acids, by oxidation, addition and substitution reactions to form DBPs such as trihalomethanes (THMs), haloacetic acids (HAAs) and other halogenated volatile organic compounds (VOCs) (Villanueva et al., 2003).

The presence of VOCs including THMs in the drinking water is the target of increasing regulation because these compounds are suspected for carcinogenicity and birth effects (Cantor, 1997; Nieuwenhuijsen et al. 2000).

Traditionally, THMs have been the most studied of the DBPs. Since the 1970's, several studies have evaluated their chemical properties, the kinetics of their formation reactions, their toxicology and human health effects (Villanueva et al., 2003 / Cantor, 1997).

Apart from THMs, other VOCs are among the most commonly found contaminants in water. Several analytical methods were developed for the determination of these VOCs in water with the Purge \& Trap / Gas Chromatography / Mass Spectrometry determination being the most sensitive and simplest one (Wang et al., 1995; Golfinopoulos et al., 2001). Numerous surveys were carried out evaluating THM content in water on the basis of regression models in order to pre-estimate their levels by monitoring other simple water parameters (Espigares, 2003; Golfinopoulos, 2002a; Golfinopoulos, 2002b).

In the present study, the levels of THMs and VOCs are determined as part of a routine monitoring program followed in the TWTP laboratory. These levels are correlated with temperature, $\mathrm{pH}$, chlorine demand, TOC and contact time. VOCs and THMs levels are monitored during a year in order to determine the possible fluctuations throughout the four seasons.

\section{MATERIALS AND METHODS}

\subsection{Sample collection}

TWTP takes its raw water from the river Aliakmonas. The treatment applied in the plant consists of the following steps (Fig. 1): pre-ozonation / pH-adjustment / coagulation / flocculation / sedimentation / rapid sand filtration / ozonation / granulated active carbon (GAC) filtration / pH-adjustment to pHs / chlorination / storage. In TWTP, the ozonation process, which aims to break down organic compounds and facilitate their adsorption on the activated carbon, also serves as a first step disinfection. Final disinfection with chlorine is applied for its residual effectiveness. Samples were collected approximately 20 min after chlorination (sampling point $A$ ), as well as after the water had remained in the storage tank for several hours (sampling point B), just before it entered the distribution system.

These two different sampling points aimed to investigate the possible increase in the VOCs levels due to the contact time of water with chlorine in the storage tank. Duplicate samples were collected from the two prementioned sampling points (Fig. 1) in 40-ml amber glass vials, capped with PTFE-faced caps (EPA, Method 524.2, Revision 4.1, 1995). Ascorbic acid (Merck, pro analysi) was added in the vials as dechlorination agent. $\mathrm{HCl}$ (4 drops $6 \mathrm{~N} / 40 \mathrm{ml}$, Carlo Erba, ISO-for analysis) was added to each sample to prevent biodegradation and dehydrohalogenation. The samples were analyzed immediately after sampling.

\subsection{Method}

The following VOCs were studied: chloroform $\left(\mathrm{CHCl}_{3}\right)$, bromodichloromethane $\left(\mathrm{CHBrCl}_{2}\right)$, dibromochloromethane $\left(\mathrm{CHBr}_{2} \mathrm{Cl}\right)$, bromoform $\left(\mathrm{CHBr}_{3}\right)$, vinyl chloride $\left(\mathrm{CH}_{2}=\mathrm{CHCl}\right)$, 1,2dichloroethane $\left(\mathrm{ClCH}_{2} \mathrm{CH}_{2} \mathrm{Cl}\right)$, trichloroethene $\left(\mathrm{ClCH}=\mathrm{CCl}_{2}\right)$, tetrachloroethene $\left(\mathrm{Cl}_{2} \mathrm{C}=\mathrm{CCl}_{2}\right)$, benzene $\left(\mathrm{C}_{6} \mathrm{H}_{6}\right)$, 1,1-dichloroethene $\left(\mathrm{Cl}_{2} \mathrm{C}=\mathrm{CH}_{2}\right)$, trans-1,2-dichloroethene $(\mathrm{ClCH}=\mathrm{CHCl})$, cis-1,2-dichloroethene $(\mathrm{ClCH}=\mathrm{CHCl})$, 1,1,1-trichloroethane $\left(\mathrm{Cl}_{3} \mathrm{CCH}_{3}\right)$, carbon tetrachloride $\left(\mathrm{CCl}_{4}\right)$, 1,2-dichloro-benzene $\left(\mathrm{C}_{6} \mathrm{H}_{4} \mathrm{Cl}_{2}\right)$, 1,2-dichloropropane $\left(\mathrm{ClCH}_{2} \mathrm{CHClCH}_{3}\right)$, toluene $\left(\mathrm{C}_{6} \mathrm{H}_{5} \mathrm{CH}_{3}\right)$, ethyl-benzene $\left(\mathrm{C}_{6} \mathrm{H}_{5} \mathrm{C}_{2} \mathrm{H}_{5}\right), \quad \mathrm{p} / \mathrm{m} / \mathrm{o}-x y l e n e$ $\left(\mathrm{H}_{3} \mathrm{CC}_{6} \mathrm{H}_{4} \mathrm{CH}_{3}\right)$, styrene $\left(\mathrm{C}_{6} \mathrm{H}_{5} \mathrm{CH}=\mathrm{CH}_{2}\right)$, 1,4-dichloro-benzene $\left(\mathrm{ClC}_{6} \mathrm{H}_{4} \mathrm{Cl}\right)$. The prementioned VOCs were analyzed by the Purge and Trap method (EPA 524.2, Revision $4.1,1995)$. In this method an inert gas is bubbled through $25 \mathrm{ml}$ of water sample causing 
the purgeable organics to migrate from the aqueous to the vapour phase. These organics are then adsorbed on a trap which, upon heating, desorbs the trapped organics onto the GC-MS system.

The prementioned VOCs were analyzed using a CDS 8000 Purge and Trap Sample Concentrator, fitted with a $25 \mathrm{ml}$ sample vessel, a $30 \mathrm{~cm}$ Trap K (VOCARB 3000, Carbopack B / Carboxen 1000 \& 1001) and a Perkin Elmer AutoSystem XL Chromatograph supported by Turbomass Gold Mass Spectrometer (Table 1).

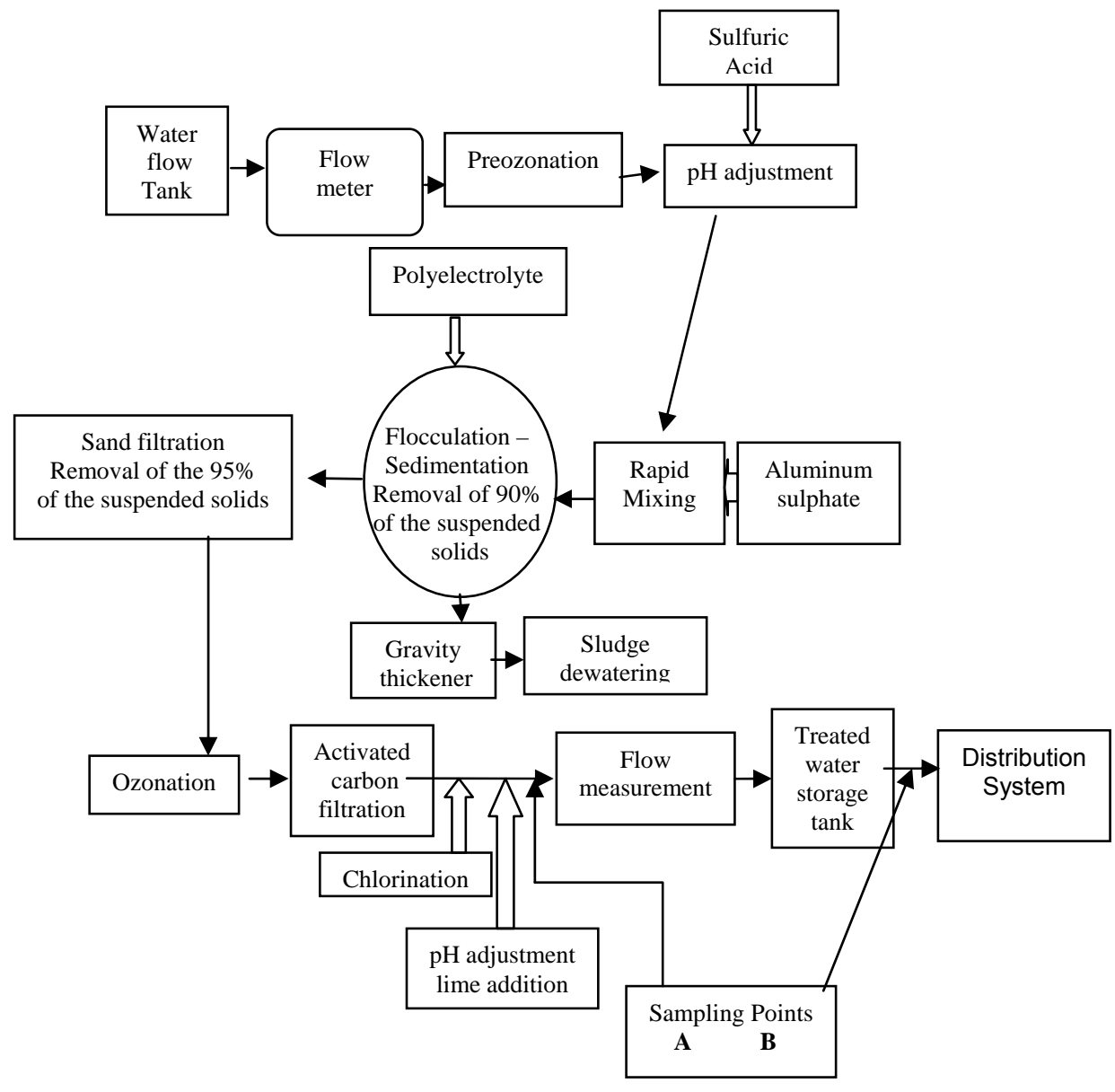

Figure 1: Thessaloniki Water Treatment Plant treatment process, sampling points A, B

The analytical quality control scheme included baseline controls, periodic analyses of certified VOCs and THM standard solutions (EPA 524.2 method, mixtures DW-VOC Mix \#1A, \#2A and THM, Restek) in methanol (Riedel de Haën, pestanal), fortified with internal standard (4-bromofluorobenzene, 524 Internal Standard/Surrogate Mix, Restek), blank water samples (ultrapure water, Easypure UV, $\mathrm{TOC}_{\max }<2 \mathrm{ppb}$, Mod. D7402-33) and laboratory fortified blank water samples (ultrapure water fortified with standard solutions). Standard solutions were prepared by injecting known volumes of the pre-mentioned mixtures to a $10-\mathrm{ml}$ volumetric flask filled with methanol (Riedel de Häen, pestanal). Laboratory fortified blank water samples were prepared by adding known volumes of VOCs and THMs standards in 25-50 ml ultrapure water. Mixing was accomplished by inverting the volumetric flask three times. 
Table 1. Purge and trap conditions

\begin{tabular}{|c|c|}
\hline \multicolumn{2}{|l|}{ Vocarb 3000 trap } \\
\hline Purge & $40 \mathrm{ml} / \mathrm{min} \mathrm{He}, 10 \mathrm{~min}$, ambient temperature \\
\hline Desorb & $30 \mathrm{ml} / \mathrm{min} \mathrm{He}, 250^{\circ} \mathrm{C}$ for $5 \mathrm{~min}$ (preheat $245^{\circ} \mathrm{C}$ ) \\
\hline Bake & $260^{\circ} \mathrm{C}$ for $10 \mathrm{~min}$ \\
\hline Temperatures & Line $150^{\circ} \mathrm{C}$, Valve $150^{\circ} \mathrm{C}$, Wettrap $200^{\circ} \mathrm{C}$ \\
\hline \multicolumn{2}{|l|}{ GC parameters } \\
\hline Oven Temperature & $40^{\circ} \mathrm{C}$ for $4 \mathrm{~min}$ \\
\hline First temperature ramp & From $40^{\circ} \mathrm{C}$ to $150^{\circ} \mathrm{C}$ at $6^{\circ} \mathrm{C} / \mathrm{min}$ \\
\hline Second temperature ramp & From $150^{\circ} \mathrm{C}$ to $180^{\circ} \mathrm{C}$ at $8^{\circ} \mathrm{C} / \mathrm{min}$ for $1 \mathrm{~min}$ \\
\hline Column & $\mathrm{Rtx}^{\circledR}-502.2,40 \mathrm{~m} \times 0,18 \mathrm{~mm}$ i.d. $\times 1 \mu \mathrm{m}$ film thickness, Restek \\
\hline Injector & Split/Splitless, $200^{\circ} \mathrm{C}$ \\
\hline Split ratio & $30: 1$ \\
\hline Carrier & Helium, $1 \mathrm{ml} / \mathrm{min}$ (purity 99,9995\%) \\
\hline \multicolumn{2}{|c|}{ Mass spectrometer parameters } \\
\hline Solvent delay & $2 \min$ \\
\hline MS temperature & $180^{\circ} \mathrm{C}$ \\
\hline MS scan program & $45-260$ \\
\hline Scan/s & 0,1 \\
\hline
\end{tabular}

Table 2. Mean recovery (\%), relative standard deviation (in parenthesis) of THMs and VOCs at five concentration levels and the MDL of these compounds

\begin{tabular}{|c|c|c|c|c|c|c|}
\hline \multirow[t]{2}{*}{ VOCs } & \multicolumn{5}{|c|}{ Concentration levels $\left(\mu \mathrm{gl}^{-1}\right)$} & $\begin{array}{r}M D L \\
\left(\mu g I^{-1}\right) \\
\end{array}$ \\
\hline & 0,1 & 0,5 & 1 & 2 & 5 & \\
\hline Chloroform & $131(14,3)$ & $107(4,2)$ & $116(9,3)$ & $111(9,5)$ & $104(6,3)$ & 0,03 \\
\hline $\begin{array}{l}\text { Bromodichlorometha } \\
\text { ne }\end{array}$ & $91(10,2)$ & $85(11,6)$ & $89,1(13,7)$ & $92(12,4)$ & $85(8,9)$ & 0,04 \\
\hline $\begin{array}{l}\text { Chlorodibromometha } \\
\text { ne }\end{array}$ & $72(14,1)$ & $67(13,6)$ & $66(19,3)$ & $61(16,1)$ & $63(14,3)$ & 0,04 \\
\hline Bromoform & $47(18,9)$ & $50(8,8)$ & $48(6,9)$ & $45(18,3)$ & $43(13,1)$ & 0,06 \\
\hline Vinyl chloride & $103(13,4)$ & $94(13,9)$ & $103(10,8)$ & $98(11,2)$ & $91(7,1)$ & 0,04 \\
\hline 1,2-Dichloroethane & $135(11,5)$ & $105(8,1)$ & $113(4,3)$ & $114(11,5)$ & $107(6,5)$ & 0,02 \\
\hline Trichloroethene & $103(14,1)$ & $99(10,5)$ & $107(2,5)$ & $107(14,6)$ & $99(7,3)$ & 0,04 \\
\hline Tetrachloroethene & $121(10,3)$ & $118(6,6)$ & $123(3,2)$ & $123(12,5)$ & $114(8,3)$ & 0,02 \\
\hline Benzene & $134(11,2)$ & $107(8,3)$ & $116(4,4)$ & $117(11,5)$ & $110(6,4)$ & 0,02 \\
\hline 1,1-Dichloroethene & $78(10,0)$ & $91(8,8)$ & $95(9,2)$ & $99(13,1)$ & $85(16,9)$ & 0,04 \\
\hline $\begin{array}{l}\text { Trans-1,2- } \\
\text { dichloroethene }\end{array}$ & $122(14,8)$ & $\begin{array}{l}132 \\
(14,0) \\
\end{array}$ & $136(3,2)$ & $136(11,2)$ & $131(6,8)$ & 0,02 \\
\hline $\begin{array}{l}\text { Cis-1,2- } \\
\text { dichloroethene }\end{array}$ & $118(7,9)$ & $116(9,9)$ & $122(3,5)$ & $123(8,1)$ & $115(4,8)$ & 0,03 \\
\hline 1,1,1-Trichloroethane & $98(12,4)$ & $90(5,4)$ & $94(11,1)$ & $108(9,8)$ & $96(8,6)$ & 0,06 \\
\hline Carbon tetrachloride & $88(15,1)$ & $95(14,3)$ & $100(11,8)$ & $106(12,7)$ & $101(8,1)$ & 0,04 \\
\hline 1,2-Dichlorobenzene & $66(9,4)$ & $65(16,4)$ & $66(13,0)$ & $67(6,1)$ & $67(8,6)$ & 0,02 \\
\hline Dichloropropane & $110(15,5)$ & $99(9,7)$ & $110(9,6)$ & $104(8,7)$ & $98(5,5)$ & 0,02 \\
\hline Toluene & $\begin{array}{l}110,2 \\
(11,0)\end{array}$ & $\begin{array}{l}118 \\
(10,3) \\
\end{array}$ & $122(6,0)$ & $121(12,5)$ & $114(6,8)$ & 0,02 \\
\hline Chlorobenzene & $103(7,1)$ & $95(12,4)$ & $112(7,5)$ & $109(10,1)$ & $103(5,9)$ & 0,02 \\
\hline Ethyl-benzene & $131(6,4)$ & $99(18,9)$ & $110(10,8)$ & $123(13,1)$ & $117(8,9)$ & 0,02 \\
\hline p-/m-xylene & $113(4,9)$ & $84(13,6)$ & $94(13,0)$ & $121(11,3)$ & $117(7,2)$ & 0,03 \\
\hline o-xylene & $109(12,3)$ & $92(7,5)$ & $102(9,5)$ & $91(12,8)$ & $100(8,9)$ & 0,04 \\
\hline Styrene & $98(8,5)$ & $87(10,1)$ & $102(9,5)$ & $91(12,8)$ & $99(8,9)$ & 0,03 \\
\hline 1,4-Dichlorobenzene & $70(14,0)$ & $67(12,3)$ & $72(11,1)$ & $86(6,5)$ & $78(7,3)$ & 0,03 \\
\hline
\end{tabular}


Preparation of vials included washing with detergent, rinsing with tap and ultrapure water, acetone (Riedel de Haën, puriss) and air drying.

The mean recoveries (Table 2$)$ were estimated at five levels $(0.1 \mathrm{ppb}-5 \mathrm{ppb})$ and ranged from $43 \%$ to $136 \%$. Linearity was routinely evaluated between 0.1 to $100 \mathrm{ppb}$ for THMs, 0.1 to $10 \mathrm{ppb}$ for trichloroethene and tetrachloroethene according to the limit set by the European Guidelines and 0.1 to $5 \mathrm{ppb}$ for the rest of the compounds. Correlation coefficients $\left(r^{2}\right)$ ranged from $0.983-0.999$.

The method detection limit (MDL) was calculated as: $\mathrm{MDL}=\mathrm{SD}^{*} t$ where SD: standard deviation and $t: 3.11$ for $12-1=11$ degrees of freedom at the $99 \%$ level from the onesided $t$ distribution table. The MDL for the majority of the compounds ranged from 0.02 to $0.04 \mathrm{ppb}$ except for $\mathrm{CHBr}_{3}$ and $\mathrm{Cl}_{3} \mathrm{CCH}_{3}$ for which it was $0.06 \mathrm{ppb}$. Calculated accuracy and precision of the method were within the limits required from European Guidelines (Table 3).

Table 3. Required characteristics according to European guidelines 98/83/EC

\begin{tabular}{|c|c|c|c|c|c|}
\hline VOCs & $\begin{array}{c}\text { Parametric } \\
\text { value } \\
\text { (ppb) } \\
\text { according } \\
\text { to } \\
\text { 98/83/EC }\end{array}$ & $\begin{array}{c}\text { Required } \\
\text { Accuracy } \\
\% \text { of } \\
\text { parametric } \\
\text { value }\end{array}$ & $\begin{array}{c}\text { Calculated } \\
\text { Accuracy } \\
\%\end{array}$ & $\begin{array}{c}\text { Required } \\
\text { Precision \% } \\
\text { of } \\
\text { parametric } \\
\text { value }\end{array}$ & $\begin{array}{c}\text { Calculated } \\
\text { Precision } \\
\%\end{array}$ \\
\hline Chloroform & & & 10 & & 3 \\
\hline Bromodichloromethane & & & 2 & & 3 \\
\hline Chlorodibromomethane & 100 & 25 & 1 & 25 & 3 \\
\hline Bromoform & & & 5 & & 4 \\
\hline Vinyl chloride & - & - & 24 & - & 5 \\
\hline 1,2-Dichloroethane & 3 & 25 & 14 & 25 & 3 \\
\hline Trichloroethene & 10 & 25 & 15 & 25 & 3 \\
\hline Tetrachloroethene & & & 10 & & 2 \\
\hline Benzene & 1 & 25 & 13 & 25 & 3 \\
\hline 1,1-Dichloroethene & - & - & 17 & - & 3 \\
\hline Trans-1,2-dichloroethene & - & - & 9 & - & 1 \\
\hline Cis-1,2-dichloroethene & - & - & 5 & - & 2 \\
\hline 1,1,1-Trichloroethane & - & - & 12 & - & 3 \\
\hline Carbon tetrachloride & - & - & 13 & - & 2 \\
\hline 1,2-Dichlorobenzene & - & - & 4 & - & 4 \\
\hline Dichloropropane & - & - & 7 & - & 1 \\
\hline Toluene & - & - & 5 & - & 1 \\
\hline Chlorobenzene & - & - & 9 & - & 1 \\
\hline Ethyl-benzene & - & - & 4 & - & 2 \\
\hline $\mathrm{p}-/ \mathrm{m}$-xylene & - & - & 6 & - & 5 \\
\hline o-xylene & - & - & 12 & - & 6 \\
\hline Styrene & - & - & 2 & - & 6 \\
\hline 1,4-Dichlorobenzene & - & - & 6 & - & 4 \\
\hline
\end{tabular}

Total organic carbon (TOC) was analyzed in a Shimadzu TOC Analyzer (TOC-V $\mathrm{V}_{\text {CSH/CSN }}$ ). Sample $\mathrm{pH}$ was measured with a portable $\mathrm{HACH}$ pH-meter fitted with thermometer and having temperature compensation.

\section{RESULTS}

The results of this study (Table 4) showed that THMs were present in all water samples analyzed. No sample exceeded the limit set by the European Guidelines (100 ppb). THM levels in all measured samples from sampling point $A$ ranged from 0,16 to $2,47 \mathrm{ppb}$ with 
an average of $0,69 \mathrm{ppb}$, while samples from sampling point $B$ ranged from 1,10 to 12,92 $\mathrm{ppb}$ with an average of $4,73 \mathrm{ppb}$. The maximum value in sampling point $\mathrm{B}(12,92 \mathrm{ppb})$ was measured in April 2004 and can be attributed to longer contact time (40h instead of $14-19 \mathrm{~h}$ usually) of water with free chlorine in the storage tank. The lowest value $(1,10 \mathrm{ppb})$ was observed in February 2005 and can be attributed to a combination of low temperature $\left(4,4^{\circ} \mathrm{C}\right)$ and short contact time $\left(t_{R}, 8 \mathrm{~h}\right)$ in the storage tank. The rest of the VOCs monitored were never detected in any of the samples.

Table 4. Data for TTHMs and VOCs

\begin{tabular}{|c|c|c|c|c|c|c|c|c|c|}
\hline $\begin{array}{l}\text { Date of } \\
\text { sampling }\end{array}$ & $\begin{array}{c}\text { THMs } \\
(p p b) \\
A\end{array}$ & $\begin{array}{c}\text { VOCs } \\
(p p b) \\
A\end{array}$ & $\begin{array}{c}\text { THMs } \\
\text { (ppb) } \\
B\end{array}$ & $\begin{array}{c}\text { VOCs } \\
(p p b) \\
B\end{array}$ & $\begin{array}{l}t_{R} \\
\text { (h) }\end{array}$ & $\begin{array}{c}\text { TOC } \\
(p p m)\end{array}$ & $p H$ & $\begin{array}{c}T \\
\left.\rho^{\circ} C\right)\end{array}$ & $\begin{array}{c}\mathrm{Cl}_{2} \text { demand } \\
(p p m), \\
\text { samp. point } \\
B\end{array}$ \\
\hline $18 / 2 / 04$ & & & 2,59 & n.d. & 19 & 0,772 & 7,26 & 5,6 & 0,38 \\
\hline $25 / 2 / 04$ & & & 3,42 & n.d. & 20 & 0,562 & 7,27 & 6,1 & 0,37 \\
\hline $10 / 3 / 04$ & & & 4,11 & n.d. & 20 & 1,012 & 7,49 & 7,6 & 0,54 \\
\hline $31 / 3 / 04$ & & & 5,46 & n.d. & 18 & 1,08 & 7,38 & 7,4 & 0,61 \\
\hline $1 / 4 / 04$ & 1,16 & n.d. & & & & 1,096 & 7,32 & 7,3 & 0,61 \\
\hline $5 / 4 / 04$ & 2,47 & n.d. & 6,69 & n.d. & 16 & 0,955 & 7,33 & 13,2 & 0,64 \\
\hline $13 / 4 / 04$ & & & 12,92 & n.d. & 40 & 1,039 & 7,57 & 16,6 & 0,89 \\
\hline $14 / 4 / 04$ & & & 8,74 & n.d. & 21 & 1,176 & 7,55 & 15,6 & 0,81 \\
\hline 19/4//04 & & & 5,42 & n.d. & 11 & 1,081 & 7,83 & 15,3 & 0,56 \\
\hline $5 / 5 / 04$ & & & 5,46 & n.d. & 18 & 1,221 & 7,58 & 17,9 & 0,49 \\
\hline $12 / 5 / 04$ & & & 4,99 & n.d. & 19 & 0,978 & 7,18 & 16,8 & 0,43 \\
\hline 9/6/04 & & & 5,77 & n.d. & 24 & 0,96 & 7,13 & 19,3 & 0,43 \\
\hline $22 / 6 / 04$ & & & 7,82 & n.d. & 26 & 0,891 & 7,25 & 20,9 & 0,47 \\
\hline $2 / 7 / 04$ & & & 6,35 & n.d. & 19 & 0,972 & 7,28 & 23,1 & 0,35 \\
\hline 29/7/04 & & & 4,23 & n.d. & 19 & 0,773 & 7,24 & 20,6 & 0,23 \\
\hline $31 / 8 / 04$ & & & 5,27 & n.d. & 18 & 0,863 & 7,21 & 21,2 & 0,17 \\
\hline 8/9/04 & & & 4,01 & n.d. & 17 & 0,826 & 7,25 & 20,7 & 0,23 \\
\hline $27 / 9 / 04$ & & & 6,25 & n.d. & 25 & 0,822 & 7,17 & 21,2 & 0,25 \\
\hline $5 / 10 / 04$ & 0,61 & n.d. & 5,66 & n.d. & 27 & 0,842 & 7,18 & 20,2 & 0,24 \\
\hline $22 / 10 / 04$ & 0,65 & n.d. & 3,84 & n.d. & 7 & 0,949 & 7,36 & 18,4 & 0,47 \\
\hline $9 / 11 / 04$ & 0,52 & n.d. & 4,19 & n.d. & 19 & 0,884 & 7,53 & 15 & 0,24 \\
\hline $19 / 11 / 04$ & 0,42 & n.d. & 3,38 & n.d. & 15 & 0,917 & 7,39 & 11,9 & 0,38 \\
\hline $22 / 11 / 04$ & 0,91 & n.d. & 2,96 & n.d. & 11 & 0,889 & 7,43 & 9,7 & 0,43 \\
\hline $8 / 12 / 04$ & 0,67 & n.d. & 2,06 & n.d. & 13 & 1,23 & 7,44 & 12,7 & 0,41 \\
\hline $23 / 12 / 04$ & 0,16 & n.d. & 1,43 & n.d. & 14 & 1,095 & 7,27 & 7,9 & 0,45 \\
\hline $5 / 1 / 05$ & 0,18 & n.d. & 1,36 & n.d. & 10 & 0,916 & 7,39 & 7,5 & 0,3 \\
\hline $25 / 1 / 05$ & 0,24 & n.d. & 2,36 & n.d. & 17 & 1,018 & 7,03 & 7,3 & 0,2 \\
\hline $2 / 2 / 05$ & 0,25 & n.d. & 1,10 & n.d. & 8 & 1,074 & 7,44 & 4,4 & 0,28 \\
\hline
\end{tabular}

\section{DISCUSSION}

Effect of contact time, $t_{R}$. It has long been recognized that the longer water contacts free chlorine the more abundant the THMs (Fleischacker, Randtke, 1983). This is confirmed in our study since THMs determined just after chlorination (sampling point $A$ ) were 3 to 10 times lower than those observed in the final reservoir (sampling point $B$ ) on the same days. As shown in Fig. 2, THM levels follow the variations of contact time. Nevertheless, there cannot be established a linear correlation between $t_{R}-$ THMs, since other parameters also influence THM levels.

The large increase in THM levels after the initial contact time of 20 min (sampling point A), suggests that NOM of the treated water reacts at a relatively slow rate and therefore should be categorized as "slow former". The time needed for the formation of THMs depends on the composition of natural organic matter (NOM), which serves as precursor 
material. Certain NOM reacts quickly to form DBPs within the first 30 min of contact and is referred to as "quick formers", while NOM that needs more contact time to form DBPs, is referred to as "slow formers" (Carlson, Hardy, 1998).

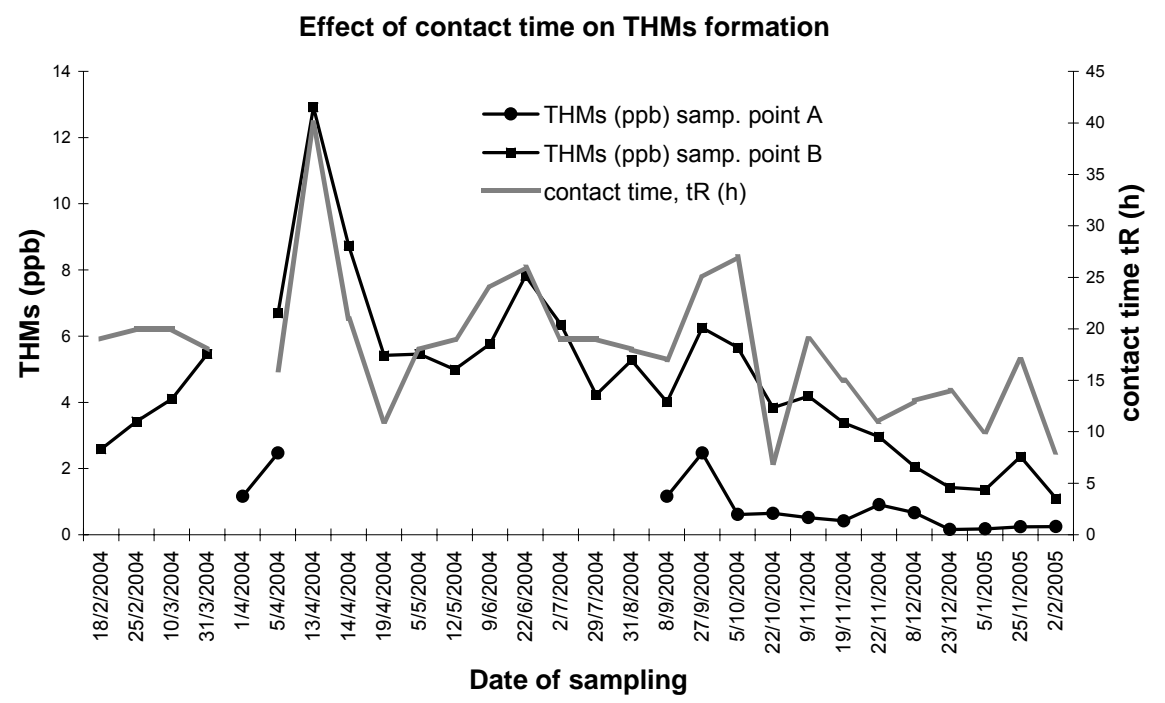

Figure 2. Effect of contact time $t_{R}$ on THMs formation

Effect of temperature. THM formation bears a strong correlation with temperature. The lower the temperature the lower the THM levels since the rate of reaction decreases. This is apparent in Fig. 3 since mostly low THM values are observed during winter.

Effect of TOC. TOC is directly correlated to NOM, the precursor for THM formation. In our case, TOC concentration is relatively stable at about $1 \mathrm{ppm}$ and as a result, no correlation can be established with that parameter (Fig. 4). The low TOC concentration is responsible for low THM levels. Ensuring low TOC levels in the treated water (before chlorination) is one of the strong advantages of the combined ozonation-GAC adsorption process applied in the TWTP. The average TOC of untreated water is 1,95 ppm. The reduction of average TOC through the treatment train is shown below:

Untreated water $\rightarrow$ After flocculation/sedimentation/filtration $\rightarrow$ After $\mathrm{O}_{3} \rightarrow$ After GAC $1,95 \mathrm{ppm}$ $1,43 \mathrm{ppm}$ $1,39 \mathrm{ppm} \quad 0,96 \mathrm{ppm}$

Distribution of THM species. The distribution of the individual THM species $\left(\mathrm{CHCl}_{3}\right.$, $\mathrm{CHBrCl}_{2}, \mathrm{CHBr}_{2} \mathrm{Cl}$ and $\mathrm{CHBr}_{3}$ ) appears in Figure 5. The relatively lower concentrations of the brominated species offers an indication that bromide ion levels in the treated prechlorinated water are low (Symons et al., 1993, Kampioti and Stephanou, 2002). 
Effect of temperature on THMs formation

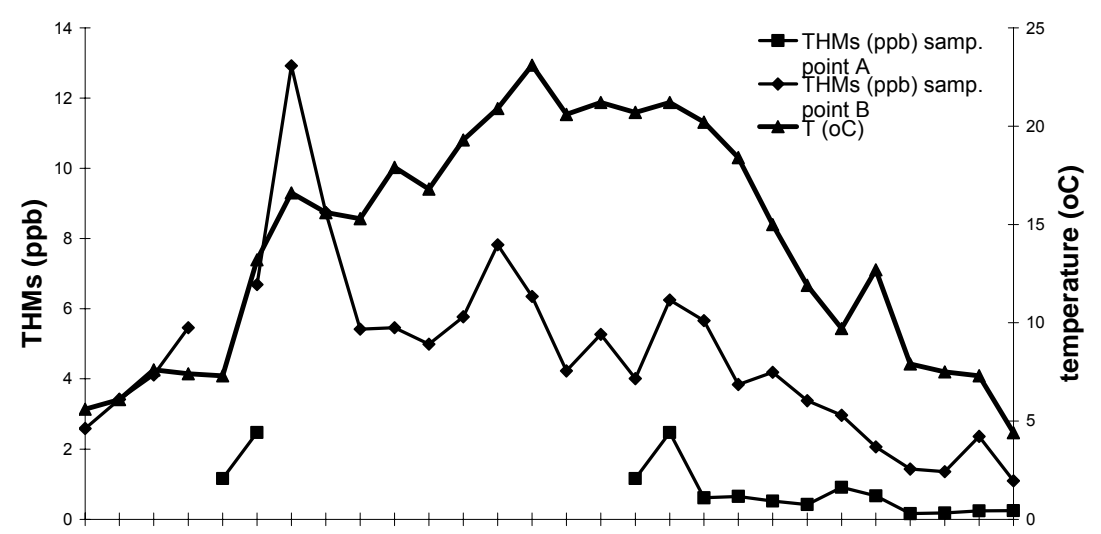

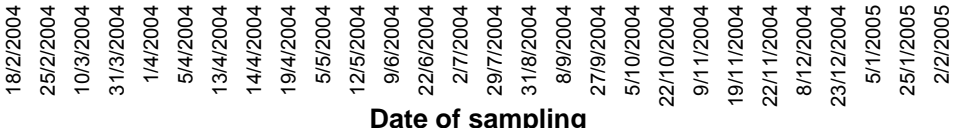

Figure 3. Effect of temperature (T) on THMs formation

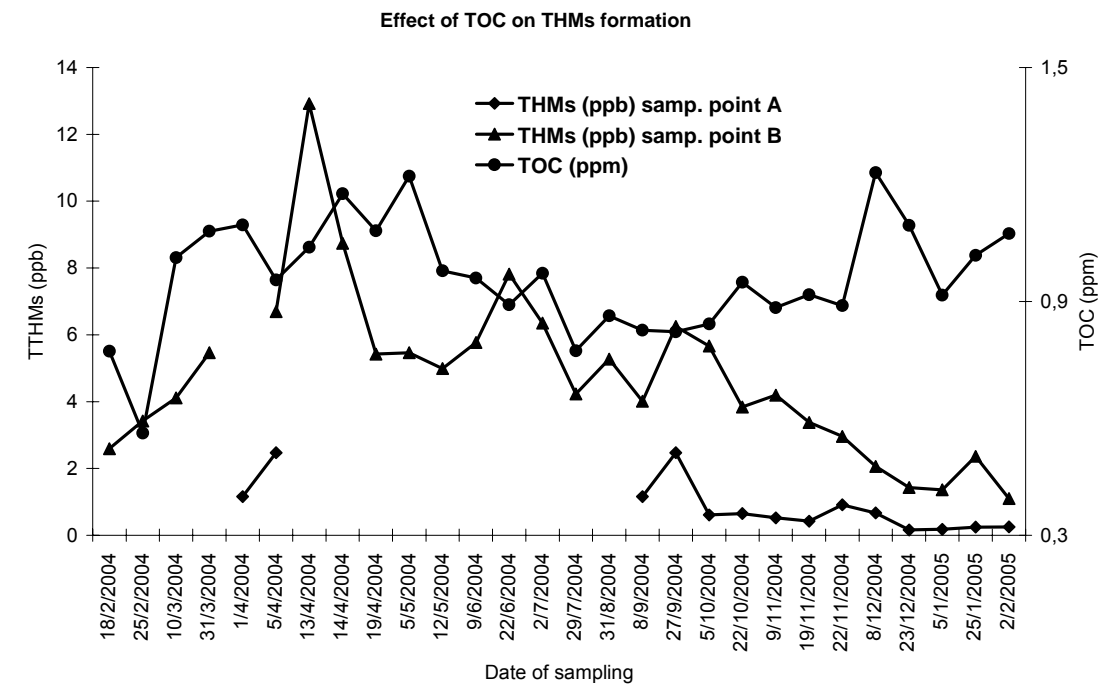

Figure 4. Effect of TOC on THMs formation

Individual THM concentrations

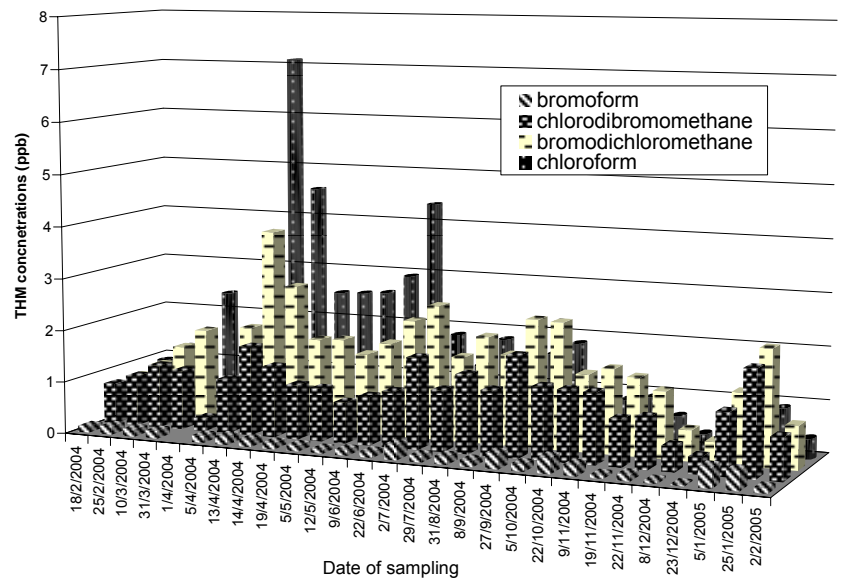

Figure 5. Relative presence of individual THMs 


\section{CONCLUSIONS}

Due to low TOC levels of the prechlorinated water and low chlorine dosage at the TWTP, THM levels of the finished drinking water are kept low. The advanced process design of the TWTP ensures maximum TOC removal through GAC adsorption and guaranteed low chlorine demand and dosage due to the preceding first disinfection step with ozonation.

Of the effects studied, free chlorine contact time $\left(t_{R}\right)$ and temperature $(T)$ appear to be the most evident regarding THM formation.

The monitoring program for the determination of VOCs in the finished drinking water of TWTP continues on a permanent basis so that consumers can freely enjoy the good quality of their water. The expansion of this program to THM formation further in the pipeline network and at the consumers' outlet is in our future plans.

\section{ACKNOWLEDGEMENTS}

We thank Christoforos D. Constantinidis-Constructing Company and the Water Authority of Thessaloniki for the financial support of this research. We also thank Dr. G. Seretoudi for her help and scientific advice, the rest of the laboratory staff of the Thessaloniki Water Treatment Plant for their contribution and $\mathrm{Mr} \mathrm{S}$. Trikis for his motivation towards the implementation of this research.

\section{REFERENCES:}

Boorman G.A., V. Dellacro, J.K. Dunnick, R.E. Chapin, S. Hunter, E. Hauchman, H. Gardner, M. Cox and R.C. Sills, Environ. Health Perpect., 107, 207-217, 1999.

Cantor, C.P., Drinking Water and Cancer causes and control, 8(3), 292-308, 1997.

Çapar, G., Yetiş, U., Wat. Res., 36, 1379-1384, 2002.

Carlson, M., Hardy, D., J. of Am. Water Works Assoc., 90(2), 1998, 95-106.

Christman R.F., D.L. Norwood, D.S. Millington, J.D. Johnson, A.A. Stevens, Environ. Sci. Technol., 17(1983), 625.

El-Shafy, M.A., Grünwald, A., Wat. Res., 34(13), 3453-3459, 2000.

Espigares, M., Lardelli, P., Ortega, P., J. of Environ. Health, 66(3), 9-13, 2003.

Fleischacker, S., Randtke, S., J. of Am. Water Works Assoc., 75(3), 1983, 132.

Golfinopoulos, S.K., Arhonditsis, G.B., Chemosphere, 47, 1007-1018, 2002a.

Golfinopoulos, S.K., Arhonditsis, G.B., Wat. Res., 36, 2856-2868, 2002b.

Golfinopoulos, S.K., Lekkas, T.D., Nikolaou, A.D., Chemosphere, 45, 275-284, 2001.

Kampioti, A.A., Stephanou, E.G., Wat. Res., 36, 2596-2606, 2002.

Nieuwenhuijsen, M.J., Toledano, M.B., Eaton, N., Fawell, J., Elliott, P., Chlorine Disinfection Byproducts in water and their association with adverse reproductive outcomes: A review., Occup. Environ. Med., 57(2), 73-85, 2000.

Rook, J.J., Water Treat. Exam., 23(1974), 234.

Symmons, J.M., Krasner, S.W., Simms, L. A., Sclimenti, M., J. of Am. Water Works Assoc., 85(1), 1993, 51-62.

Villanueva, C.M., Kogevinas, M., Grimalt, J.O., Wat. Res., 37, 953-958, 2003.

Wang, H., Simmons, M., Deininger, R., J. of Chromatograph. Sci., 33, 109-112, 1995. 